\title{
Reply to comment of R.S.J. Sparks, H.E. Huppert, and C.J.N. Wilson on "Evidence for long residence times of rhyolitic magma in the Long Valley magmatic system: the isotopic record in precaldera lavas of Glass Mountain"
}

\author{
Alex N. Halliday \\ Department of Geological Sciences, University of Michigan, Ann Arbor, MI 48109-1063 (U.S.A)
}

Received May 7, 1990; accepted May 14, 1990

\section{Introduction}

I thank Sparks, Huppert and Wilson [1] for the compliments they pay to our recent paper [2] and the interesting points they raise in their discussion. At the outset it should be made clear that this paper was the final product of considerable debate, which resulted in the repeat $\mathrm{Rb}-\mathrm{Sr}$ analysis of every rhyolite we initially studied plus the analysis of additional samples, purely because we had trouble accepting the radical implications of our own data. I am therefore not at all surprised that the paper has generated discussion and indeed welcome the opportunity to explore the matter further.

Sparks et al. suggest that the data for the Glass Mountain rhyolites can be better accounted for by a model of episodic remelting of separate bodies of granite rather than by our model of eruptions from a persistent high-level magma reservoir. In our paper we made it clear that there was more than one possible interpretation of the geometries of the magma bodies from which the rhyolites were erupted, including stable layers in a roof zone of a single large chamber and subjacent magma cupolas. The crux of our differences then, centres on whether the rhyolites have been derived by episodic tapping from long-lived bodies of magma (of whatever geometry) or by repeated melting of granitic rocks.

The favoured model presented here, and in Halliday et al. [2] is of a stable, high-level, stratified magma body which does not undergo convec- tive overturn on a large scale, but which may convect in small cells within the layers. One of the most powerful supporting lines of evidence for this is the existence of marked vertical temperature gradients in large volumes of silicic magma as recorded, for example, in the Bishop Tuff [3]. It is difficult to conceive of a mechanism by which such gradients are produced or preserved if there is rapid large-scale convective overturn in the magma. Furthermore the presence of phenocryst assemblages which appear to have been in chemical equilibrium with their host magma compositions and which are a function of magma temperature (as in the Bishop Tuff) suggests that for at least some high silica rhyolites, there was no major movement of crystals through the magma [3]. Although we did consider the possibility that the different isochrons in the Glass Mountain rhyolites reflected tapping of separate magmas from subjacent cupolas [2], the problems of keeping the systems hot for long periods are exacerbated further if they are separated, and this solution was therefore considered less likely.

Sparks et al. raise two objections to the longlived layered magma chamber hypothesis of Halliday et al., namely space-time problems of mixing of magma from different layers and thermal problems. This reply first presents the case that the model of Sparks et al. is in fact less reasonable than our own and is incapable of accounting for the trace element and isotopic characteristics of the Glass Mountain rhyolites, and then addresses and discusses the problems which they raise with 
our own model. Finally, the areas of future research which are considered to be most critical at this stage are highlighted.

\section{Why long-lived magma chambers are a better explanation than repeated melting of the crust}

The model of episodic remelting of granite which Sparks et al. propose is inconsistent with the data for Long Valley. Sparks et al. [1] refer to the paper by Huppert and Sparks [3] in which their model is developed in more detail. This model involves melting at some depth $(>15 \mathrm{~km})$ at which the ambient crustal temperatures are more than $500^{\circ} \mathrm{C}$.

(1) The preservation of source $\mathrm{Rb}-\mathrm{Sr}$ isochrons in rhyolites (as Sparks et al. view the data for Glass Mountain), is inconsistent with the fact that $\mathrm{Rb}$ and $\mathrm{Sr}$ have very different bulk distribution coefficients in the granite system. ( $R b$ is a moderately incompatible element and $\mathrm{Sr}$ is a strongly compatible element.) For this reason the only episodic melting scenario possible for the Glass Mountain rhyolites is repeated $100 \%$ extraction of the source (melt plus restite) for every rhyolite flow, otherwise the $\mathrm{Rb} / \mathrm{Sr}$ ratios will be fractionated. Given that the rhyolites are virtually aphyric, this further implies that the magmas were mobilised at almost $100 \%$ melting, (unless there was considerable resorption during ascent), whereas granite magmas are normally mobile at $10-50 \%$ partial melting [5-7].

(2) The exact location for the rise of magma batches from a melting granite will be dictated not by high-level conduit systems above (as in our model), so much as by the location of melting (below). This leaves us with the only source geometry that is consistent with the hypothesis of Sparks et al. and the outcrop pattern, as two elongate, immediately subjacent bodies of granite which do not overlie each other, are about $4 \mathrm{~km}$ wide, and at least $15 \mathrm{~km}$ in length. According to the model of Sparks et al., these bodies have to episodically melt, approximately side by side, without mass transfer between them in order to preserve the $\mathrm{Rb}-\mathrm{Sr}$ isochrons and produce the eruption history observed. In addition, the low $\mathrm{Sr}$ concentrations of the rhyolite magmas (down to $0.1 \mathrm{ppm}$ ) preclude any contact between the granite sources and the basalts (which typically contain about 1000 ppm $\mathrm{Sr}$ in this region) which supposedly caused the melting. The magmas would also have to rise through a considerable depth of the continental crust (greater than in the magma chamber model) without interacting at all with the crust en route from melt zone to the surface since otherwise both the $\mathrm{Rb}-\mathrm{Sr}$ isochrons and the low $\mathrm{Sr}$ concentrations would be destroyed. The country rocks contain 100-1000 ppm Sr. This seems to effectively rule out "normal" emplacement mechanisms in which the crust and the magma are expected to interact, such as diapirism and stoping. In short, the magma transport problems implied by the model of Sparks et al., and outlined above, are far greater than those posed in our own model. At this point, Halliday et al. lose the glamorous title of "most incredible hypothesis"!

(3) To our knowledge there is no granite on Earth that has been reported with the low $\mathrm{Sr}$ concentrations (down to $0.1 \mathrm{ppm}$ ) observed in the Glass Mountain rhyolites. In view of the vast amount of high-quality isotope dilution $\mathrm{Sr}$ data that has been generated in the $\mathrm{Rb}-\mathrm{Sr}$ dating of granites, it seems unlikely that such magmas ever crystallize in the deep crust in significant volumes, as required by the Sparks et al. model.

(4) The low $\mathrm{Sr}$ concentrations of the Glass Mountain rhyolites cannot be generated by melting of any "normal" source rock because it is impossible to produce the extreme depletions in $\mathrm{Sr}$ by batch melting (Fig. 1). Small degree fractional melting is largely inapplicable to granite magmas since their viscosity inhibits separation of small melt fractions. The very existence of such low $\mathrm{Sr}$ magmas requires that at some point either the magma (Halliday et al. model) or the magma source (Sparks et al. model) underwent Rayleigh fractional crystallization involving substantial volumes of cumulates $\left(>10^{3}\right.$ times the erupted volume) (Fig. 1). This is irrespective of erupted isochrons, conduits, or thermal arguments! The obvious way to achieve this is to have a large magma reservoir from which the Glass Mountain rhyolites were erupted. If the Glass Mountain rhyolites have, instead, been produced by direct melting of granite as Sparks et al. suggest, the protolith has to be the product of extreme fractional crystallization. In other words, the protolith granites from which the rhyolite melts are derived according to the hypothesis of Sparks et al. have 


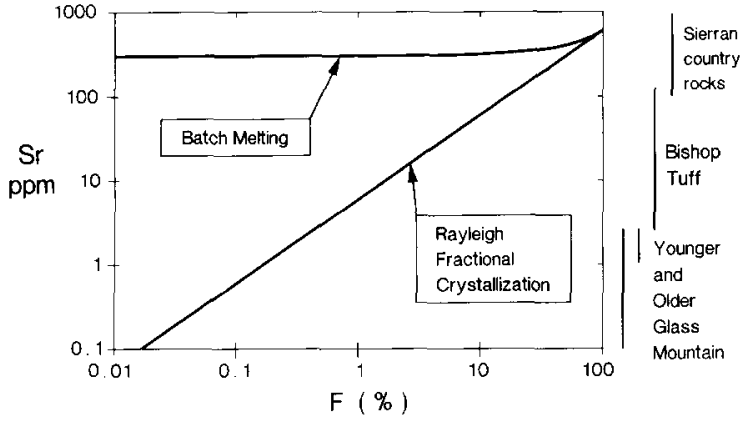

Fig. 1. Plot of Sr concentration as a function of melt fraction $(F)$ for Rayleigh fractional crystallization and batch melting. For simplicity both curves are calculated with a constant bulk distribution coefficient of 2 and the same starting composition (parent magma or source respectively) of $600 \mathrm{ppm} \mathrm{Sr}$. It is impossible to produce the low $\mathrm{Sr}$ concentrations in the Glass Mountain rhyolites (down to $0.1 \mathrm{ppm}$ ) without the magma itself or a protolith of the magma, undergoing extreme Rayleigh fractional crystallization, accompanied by the formation of substantial volumes of cumulates.

to be minor parts of very big $\left(>10^{4} \mathrm{~km}^{3}\right)$ highly differentiated bodies in the deep crust. The model of Sparks et al. requires that these large granitic bodies crystallized in the deep crust side by side at the time defined by the isochrons. It seems implausible that the only expression of their existence was the episodic remelting from below of only the most evolved portions. Furthermore, it seems unlikely that rhyolites derived by melting of these substantial bodies in the deep crust were erupted through several separate conduit systems immediately adjacent to each other in a restricted area on the NE corner of the future Long Valley caldera with no mixing.

In summary, the model of Sparks et al. is not considered a better explanation than our own for the genesis of the Glass Mountain rhyolites. It is recognized that accounting for large, long-lived, stable, highly fractionated bodies of silicic magma at shallow depths in the Earth's crust may be a problem [2], but the alternative model proposed by Huppert and Sparks [4] and Sparks et al. [1] is unreasonable in the case of Glass Mountain.

\section{Space-time problems of magma mixing}

Sparks et al. correctly point out that, according to our specific "isochron layer" model (which we did emphasise more than other models), lavas from different layers of the body of magma (the $\mathrm{Rb}-\mathrm{Sr}$ data for which define separate isochrons) were erupted adjacent to each other, and consider it difficult to conceive of a mechanism by which these magmas can have failed to mix. The examples they cite, units $\mathrm{ON}$ and $\mathrm{OP}$, represent an unfortunate choice because the $\mathrm{Rb} / \mathrm{Sr}$ ratios of both are relatively low, thereby making their assignment to a specific isochron less certain than for some other examples. In this respect units $\mathrm{OB}$ and $\mathrm{OC}$ are better choices since both have very high $\mathrm{Rb} / \mathrm{Sr}$ ratios and clearly relate to separate isochrons despite being subjacent in outcrop.

Environments in which mixing can occur can be divided into conduit systems on the one hand and magma reservoirs on the other. Maintaining isolated conduits for the eruption of lavas is in fact considerably less of a problem for the magma chamber model of Halliday et al. than the melting model of Sparks et al. (as pointed out above). In our model, the separation between the erupted magmas is a predictable consequence of the intersection of conduits with the surface defined by the roof and walls of the magma chamber. The conduits will tap whatever is immediately below that surface at the point of intersection. The separation at surface outcrop of isochrons relating to different layers will persist unless the magma in the chamber moves significantly. In the case of Glass Mountain, individual eruptive units are small, and since most were emplaced as lavas the eruptive rates were slow (compared with pyroclastic eruptions). If subjacent lavas are erupted at approximately the same time, the amount of movement in the magma chamber (as a result of magma withdrawal say) between eruptions will be relatively small. Preventing mixing between the layers in the chamber depends on the integrity of the boundary which in detail is something of an unknown but relates to the stability of the layers and the relative and absolute viscosities. Both the high viscosity and the small viscosity contrast between layers of high-silica rhyolite mitigates movement of the interface of the two layers, both generally and specifically during eruption. These features lend credibility to the hypothesis of persistent, stable bodies of magma which do not mix over long periods, even as adjacent horizontal layers in a chamber. If the layers internally convect, then there could be entrainment of material from the 
interface. This has to be minimal to preserve the isochrons.

\section{Thermal constraints}

The second problem that Sparks et al. raise is with the mechanism for maintaining highly evolved rhyolite magmas for periods of more than $10^{5}$ years at shallow depths in the continental crust, without differentiation or cooling. In response we should first clarify the interpretation of the isochrons. As discussed in detail in our paper, the preservation of the isochrons is inconsistent with mixing between layers but does not preclude mixing (hence convection) within a layer so long as the range in $\mathrm{Rb} / \mathrm{Sr}$ is not eliminated. Furthermore, the existence of the isochrons does not preclude separation of early-formed crystals, at any time, provided they have not re-equilibrated isotopically with the magma. Neither are the whole rock systematics inconsistent with late crystallization of phenocrysts, provided these did not separate from the magma. Finally, the slopes of the whole rock isochrons are not affected by resorption of phenocrysts during heating of the rhyolitic liquid. In fact, if there has been no crystal settling and no re-equilibration, there will be no way of recognizing the effects of resorption.

The mineral-glass isotopic systematics are the subject of ongoing research at the University of Michigan, and it would be premature to commit ourselves to models of crystallization processes within the layers (which these data may reveal) at this stage. Nevertheless, it would be reasonable as far as the published data base is concerned to present two alternative hypotheses:

(1) Each layer removes heat by convection in several small subjacent cells. Minor crystallization and resorption take place at the top and bottom, respectively, of each cell, but the viscosity is too great to permit crystal separation. The thermal boundary layer between the convecting layers must be maintained by a stable density stratification.

(2) An alternative model is that the magmas are too viscous to convect at all on a reasonable timescale. The magmas transfer heat purely by conduction through the magma and the chamber walls, and this has the effect of very slowly crystallizing the margins and roofs of the magma body. The temperature of the layers is ultimately maintained by very slow conductive cooling from the top and by heat supplied from advection of deeper parts of the magma systems, or by intrusion of magma deep within the crust. If there is a rise in temperature, some of the crystals are resorbed. Heat is also released from the system if some of the magma is erupted. If the system is too viscous to convect, the rate of heat transfer within the system will be reduced dramatically.

The bottom line with both models is that the major rate-controlling process on heat loss from the magma is conduction through the walls even if the magma does convect [8], and the problems of retaining low-temperature magmas at high levels in the crust are simplified to maintaining a reasonably constant modest heat flux from deeper levels.

Apart from thermal considerations, the "survivability" of a high-level body of rhyolite magma with $0.1 \mathrm{ppm} \mathrm{Sr}$ will depend on the integrity of the chamber roof zone and walls on the one hand, and the interface with underlying less evolved magmas supplying heat to the system. The roof and walls should be made up of chilled margins which at high temperatures will be relatively plastic and will flow and heal breaches to accommodate changes in the stress system. The main body of the magma will therefore be shielded from interactions with country rock which might induce rapid cooling, fractional crystallization, contamination and instability. Some such shielding is essential if the magmas are to preserve their extremely low $\mathrm{Sr}$ concentrations.

If it is necessary to maintain heat in the system by transfer from an underlying, more primitive magma (as suggested by Halliday et al. [2]), the question arises as to how long a rhyolite body can maintain its distinctive chemical (and in this case isotopic) identity if there is a conductive interface between the two systems across which heat is being transferred. This has recently been modelled $[9,10]$, and it can be shown that, depending on the exact physical properties of the magmas, a system can remain stable for very long periods, comparable to that required in the case of Glass Mountain $\left(10^{5}-10^{6}\right.$ yrs).

\section{Future research}

The data from Glass Mountain demonstrate the power of the $\mathrm{Rb}-\mathrm{Sr}$ technique for determining 
rates of differentiation of rhyolitic magmas that have high $\mathrm{Rb} / \mathrm{Sr}$ ratios. As such it should be utilized to maximum advantage in order to make progress in this field. The determination of the longevity of the magma system requires independent constraints on the timing of eruption. This was acknowledged by Halliday et al. as the most likely cause of error in the model for Glass Mountain. Currently, the best hope for accurate determination of eruption age is low-background ${ }^{40} \mathrm{Ar}-{ }^{39} \mathrm{Ar}$ dating. We have now confirmed the $\mathrm{K}-\mathrm{Ar}$ ages for Glass Mountain rhyolites given in Metz and Mahood [11] at the University of Michigan, using low backround ${ }^{40} \mathrm{Ar}-{ }^{39} \mathrm{Ar}$ dating of pristine glass, and are in the process of conducting similar measurements on mineral separates. If the eruption ages have been accurately determined, then the model of long-lived magma bodies presented by Halliday et al. still appears to be the best explanation.

\section{Acknowledgements}

Isotopic research on silicic volcanism at the University of Michigan is supported from NSF grants EAR-8616061, EAR-8720564 and EAR9004133 to ANH and RII-8800088 to GAM, as well as by the Scott Turner Fund. ANH thanks Gail Mahood, Frank Spera, Gareth Davies, and Klaus Mezger for discussion.

\section{References}

1 R.S.J. Sparks, H.E. Huppert and C.J.N. Wilson, Comment on "Evidence for long residence times of rhyolitic magma in the Long Valley magmatic system: the isotopic record in precaldera lavas of Glass Mountain" by A.N. Halliday, G.A. Mahood, P. Holden, J.M. Metz, T.J. Dempster and J.P. Davidson. Earth Planet. Sci. Lett. 99, 387-389, 1990 (this issue).

2 A.N. Halliday, G.A. Mahood, P. Holden, J.M. Metz, T.J. Dempster and J.P. Davidson. Evidence for long residence times of rhyolitic magma in the Long Valley magmatic system: the isotopic record in precaldera lavas of Glass Mountain. Earth Planet. Sci. Lett. 94, 274-290, 1989.

$3 \mathrm{~W}$. Hildreth, Gradients in silicic magma chambers: Implications for lithospheric magmatism. J. Geophys. Res. 86, 10153-10193, 1981.

4 H.E. Huppert and R.S.J. Sparks, The generation of granitic magmas by intrusion of basalt into continental crust. $J$. Petrol. 29, 599-624, 1988.

5 A.A. Arzi, Critical phenomena in the rheology of partially melted rocks. Tectonophysics 44, 173-184, 1978.

6 D. McKenzie, The extraction of magma from the crust and mantle. Earth Planet. Sci. Lett. 74, 81-91, 1985.

7 S.M. Wickham, The segregation and emplacement of granitic magmas. J. Geol. Soc. Lond. 144, 281-297, 1987.

8 C.R. Carrigan. The Biot number and the thermos bottle effect: implications for magma chamber convection. Eos Trans. AGU 67, p. 1264, 1986

9 C.M. Oldenburg, F.J. Spera, D.A. Yuen and G. Sewell, Dynamic mixing in magma bodies: theory, simulations, and implications. J. Geophys. Res. 94, 9215-9236, 1989.

10 A.F. Trial and F.J. Spera, Mechanisms for the generation of compositional heterogeneities in magma chambers. Geol. Soc. Am. Bull. 102, 353-367, 1990.

11 J.M. Metz and G.A. Mahood, Precursors to the Bishop Tuff eruption: Glass Mountain, Long Valley, California. J. Geophys. Res. 90, 11121-11126, 1985. 